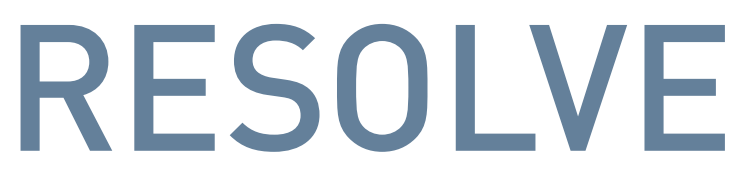

N E T W O R K
RESOLVE NETWORK RESEARCH BRIEF

NO. 2 | LAKE CHAD BASIN RESEARCH SERIES

FEBRUARY 2019

\title{
The State of Secularism in Chadian Higher Education Testing Perceived Ties to Violent Extremism
}

\author{
Remadji Hoinathy and Daniel Eizenga
}

\section{Key Findings}

- Debates about the secular character of the state and the role of religion in the public sphere in the Lake Chad Basin reveal important socio-religious divisions in higher education. If left unaddressed, these divisions, coupled with other social grievances, could increase social polarization and facilitate the spread of extremist sentiment.

- The number of higher education institutions in Chad has increased since the 2000s, providing increased access to universities for citizens. Still, low enrollment rates, recent austerity measures, and questions regarding the erosion of the secular nature of higher education institutions have had adverse impacts, as well as the potential to foster further grievances.

- Despite the state's secular commitments to and oversight of higher education, non-state religious organizations wield significant influence over certain components of Chad's higher education system - including confessional universities and a semi-public university that is funded at least in part by the government; curricula; and language teacher training.

- Higher education in Chad is committed to bilingualism. In practice, however, education is subject to divisions between the country's two official languages, French and Arabic, which separate university students, faculty members, and administrators. These language divisions frequently correspond to or overlap with the religious identifications of students and faculty members and limit opportunities for some students.
ABOUT THE RESEARCH

In July 2017, the RESOLVE Network launched a research project in the Lake Chad Basin to assess the role of the state, civil society, and other non-state actors in shaping the political divides over the role of religion in education and community and state responses to extremism in Chad, Nigeria, and Cameroon. The RESOLVE Network offers an innovative means of helping USAID and other U.S. government partners interested in testing assumptions embedded in their theories of change about the effectiveness of $P / C V E$ interventions in the educational arena.

For more on the project, please visit:

https://resolvenet.org/ 
- State and government policies that support bilingualism and that are perceived as promoting favoritism of one religion over others run the risk of exacerbating interand intra-religious tensions. Such an effect could contribute to the erosion of the state's secular character and increase the vulnerability of Chad to violent extremist threats and actors such as Boko Haram.

\section{Executive Summary}

Over the past decade, the violent extremist group Boko Haram has spread from northeastern Nigeria across the borders of its neighboring Lake Chad Basin states, recruiting new members, spreading its hateful ideology, and carrying out violent attacks on local populations and state apparatuses. In 2015, Boko Haram orchestrated multiple suicide bombings in N'Djamena, the capital of Chad; it has conducted additional attacks in the state since then. Chadian security forces have largely held the group at bay, sparing Chadians from the number and extent of attacks seen in neighboring countries. Still, Boko Haram's influence across the region has raised alarm about the expansion of violent extremism in new areas and renewed efforts to prevent and counter it.

Many studies point to a confluence of factors - including poverty, marginalization, and lack of education - implicated in the spread of Boko Haram throughout the region. Few studies, however, have investigated the extent to which debates over the role of religion in the higher education system may contribute to support for or opposition to violent extremist groups, ideologies, and tactics. As noted in a recent RESOLVE Network report, greater attention to the role of higher education as a potential bulwark to or facilitator of the spread of violent extremism in the Lake Chad Basin is needed, given evolving dynamics and trends that have the potential to impact popular sentiments on such actions and ideas. ${ }^{1}$

In Chad, specifically, issues associated with the secular nature of the state and education system, coupled with the rising influence of religious instruction and organizations in higher education, necessitate more in-depth study and analysis. The rate of higher education enrollment in Chad is lower than in neighboring Cameroon and Nigeria; however, those who do attend university form an elite cadre of individuals with greater opportunity and access to positions in policy creation and governance.

This research brief offers an initial assessment of students', teachers', and other actors' perceptions of secularism at institutions of higher education in N'Djamena. Informed by interviews and focus group discussions with key stakeholders in Chad's higher education sector, it evaluates the implementation of secular policies and curricula within the context of higher education in the country. By analyzing perceptions of secularism and ongoing debates concerning the role of religion in public life at institutions of higher education, this research brief addresses the various intellectual currents present in contemporary Chadian politics and society and seeks to identify issues - current and potential — relevant to crafting effective and proactive interventions to prevent and counter violent extremism (P/CVE).

\footnotetext{
${ }^{1}$ Alexander Thurston, "Campuses and Conflict in the Lake Chad Basin: Violent Extremism and the Politics of Religion in Higher Education." RESOLVE Network Research Report no. 1, 2018, Lake Chad Basin Research Series. The report, also part of the RESOLVE Network Lake Chad Basin Research Series, explores the evolution of higher education in Cameroon, Chad, Niger, and Nigeria; the role of religion on university campuses and intersections with violent extremism; and trends warranting further attention from $\mathrm{P} / \mathrm{CVE}$ policymakers, practitioners, and researchers moving forward.
} 
This RESOLVE Network research brief is part of a series of publications on similar dynamics in the region and builds on the findings identified in RESOLVE's "Campuses and Conflict" report. ${ }^{2}$ The research brief illuminates several trends related to the politics of religion in higher education that have potential implications for P/CVE efforts. First, while secularism is widely accepted in principle, several interpretations and perspectives on the proper role of religion in the public space are being advanced and debated by Chadian intellectuals and students on university campuses and in classrooms. In a country like Chad, those intending to radicalize others and spread violent extremism may find additional openings to exploit, if debates over the proper place of religion in the public sphere appear to be increasing.

Research conducted for this brief also revealed important insights into the languagereligion nexus in Chadian higher education. The bilingual character of the state carries into curricula and instruction in higher education environments. However, the diversity of the curricula taught to students studying in one language versus those studying in another — sometimes involving subject matter that is religious in nature - often inadvertently creates divisions within student bodies, departments, and university administration. These language divisions typically overlap with religious identification and, in turn, correspond with perspectives on secularism. The divisions can have farreaching implications, affecting students' opportunities on campus and post-graduation, particularly for non-Arabic-speaking and non-Muslim students, and have the potential to increase perceptions of alienation and marginalization. This is particularly applicable to Muslim and Arabic-speaking students, who have historically felt excluded from public higher education.

Finally, this study finds that the role of the state in regulating the secular character of public higher education may be diminishing. This role, coupled with a recent reform of the constitution that some perceived as undermining the secular nature of the state itself, risks exacerbating tensions between and within religious communities and providing a space in which violent extremist actors and ideologies could take root.

To address these issues and diminish the possibility of further polarization and conflict, the research brief recommends the following:

- Work to maintain the state's neutrality in the regulation of religious issues in the country in general and in higher education curricula in both Arabic and French in particular. For example, a standardized set of criteria to evaluate student progress toward a degree, regardless of language or religious background, could be used across all public institutions of higher education.

- Ensure that universities and other institutions of higher education remain environments for the open debate of ideas and aim to improve cross-cultural interactions to overcome linguistic and religious divisions on campuses. Efforts to improve interactions should target students, faculty members, and administrators of higher education.

- Support additional research on the continued rise of religious fundamentalism in public debates, both on and off campus. 


\section{Introduction}

The spread of Jamaat Ahl as-Sunnah lid Dawah wal Jihad, more commonly known as Boko Haram, across borders in the Lake Chad Basin has renewed focus on elucidating the extent to which violent extremist sentiments and groups have gained traction among local populations. Equally important to $\mathrm{P} / \mathrm{CVE}$ policies and practice moving forward is a more in-depth understanding of the lived experiences of local populations and the factors and dynamics that carry the potential to increase either their resiliency or susceptibility to violent extremist rhetoric and actions. Despite Boko Haram attacks and evidence of recruitment (mostly in the region around Lake Chad), few studies have been conducted on the nature or drivers of violent extremism in Chad. Fewer still have been conducted on the intersection of religion and higher education, and on how dynamics therein may be intertwined or interact with violent extremist groups and trends.

Boko Haram has built a following based on its complete rejection of Western-style education and secular government and its advocacy of a violent extremist interpretation of governance and religion. In Chad, this position represents an extreme view within a much broader debate over the character of the state and the appropriate boundaries between public and religious affairs. The renewed importance of this debate, given its implications for social divisions and dynamics, reveals important insights that can inform more effective and proactive strategies to increase the resiliency of Chadian society.

This research brief focuses on illuminating the dynamics related to, and contemporary interpretations of, secularism in institutions of higher education in Chad. It explores their implications, if any, for support for or resilience to violent extremism in order to better inform policy and practice. The research brief gives particular attention to the growing importance of religious actors in this context, elaborating on issues raised in a recent RESOLVE Network report, "Campuses and Conflict in the Lake Chad Basin." Secularism, as defined herein, refers to a conception and organization of society based on the separation of religious and public spheres as they pertain to the exercise of public power. Insights presented in this research brief draw on dozens of interviews and other observations related to the role of religion in politics on campuses, mainly in the capital city of N'Djamena. The research also includes intensive monitoring of the March 2018 national forum ${ }^{4}$ and a daily ethnography on the Chadian blogosphere and social media.

This brief provides much-needed insight to those seeking to understand linkages among violent extremism, secularism, and higher education in Chadian contexts. Given the sensitivity in Chadian society to Boko Haram, extremism, and religious issues in general, research conducted for this research brief focused on debates over the role of religion in the public sphere as an indirect means of facilitating open discussion of the various religious discourses — including those regarding violent extremism — engaged in debate. Future research should further elaborate the findings presented in this research brief in Chad and in other contexts worldwide.

\footnotetext{
${ }^{3}$ Alexander Thurston, "Campuses and Conflict in the Lake Chad Basin: Violent Extremism and the Politics of Religion in Higher Education.” RESOLVE Network Research Report no. 1, 2018, Lake Chad Basin Research Series.

${ }^{4}$ For additional information on the forum, see: https://www.reuters.com/article/us-chad-politics/chads-president-could-stay-on-until2033-under-proposed-reforms-idUSKBN1H41R1.
} 


\section{Methodology}

Research for this brief took place through an empirical field study that was conducted primarily in N'Djamena, where most institutions of higher education are based. The authors conducted interviews at three levels:

- The decisional state level: At the decisional level are the actors in charge of designing and implementing higher education policy, for example, the Ministry of Higher Education and Scientific Research (Ministère de l'Enseignement Supérieur, de la Recherche Scientifique et de l'Innovation). Non-state actors like the High Council for Islamic Affairs (Conseil Supérieur des Affaires Islamiques, CSAI) and the Islamic Educational Scientific and Cultural Organization (ISESCO) represent important actors in this context.

- The operational level: At the operational level are the universities and their administrators. The institutions included in this study are King Fayçal University (URF) $^{5}$; the University of N'Djamena; and cultural centers that are sponsored by foreign state funds and non-state institutions implicated in the debate on secularism, including Centre Al-Mouna and Centre d'Etudes et de Formation pour le Développement (CEFOD), two Catholic institutions well known in the country.

- The community level: At the community level, the authors met with leaders of civil society associations focused on inter-confessional discussions in the country that were of interest to the research. We discuss these institutions in more detail in the findings section. The authors also organized focus group discussions with students from the URF and the University of N'Djamena to understand how their curricula shape their perceptions of secularism. ${ }^{6}$

The research included a series of expert interviews with university, religious, civil society, and state officials. Interviewees were selected based on their public status in these domains or their public views on secularism. The research included a focus group discussion with university students to better understand how their curricula shape their perceptions of secularism. Initial participants in the study were identified through previous projects and collaborations and participants publicly known to have expert knowledge, involvement, and/or interest in the specific issues related to religion and politics in Chad. The authors also interviewed additional participants from news accounts, public reputation, and/or leadership positions at universities, religious institutions, and public bureaucracies. $^{7}$

The initial list of participants included public figures associated with nongovernmental organizations, government officials, civil society organizations, bureaucracies, and

\footnotetext{
${ }^{5}$ In French, Université Roi Fayçal (URF).

${ }^{6}$ In the future, the authors hope to organize public debates, roundtables, and focus groups comprised of students and experts to gather more information on how these groups understand and evaluate the role of religion in politics.

${ }^{7}$ After their interviews, the authors employed the well-known technique of "snowballing" or chain referral sampling. These forms of non-probability sampling strategies are entirely appropriate for collecting cultural data from experts (Bernard 2011). The technique refers to a practice whereby interviewers ask interviewees to voluntarily submit their recommendations of other relevant actors to interview. This technique helped the authors identify important social networks between professionals and experts debating the secular character of the Chadian state.
} 
leading media organizations. The "snowballing" technique of requesting contacts from participants helped to expand this foundation into a larger group of experts on these topics. The authors always asked for permission to mention the person who had suggested a new interviewee in setting up subsequent interviews. Participants were assured that they would not be identified in reports and publications resulting from this research. The number of interviewees was not set in advance and was ultimately determined by pragmatic considerations, including the availability of individuals. Interviewees varied in age, but all were adults over 18 years old. There was no compensation for interviews. ${ }^{8}$

Several unpredictable limitations arose during the research process. The research occurred during a particularly tense period in the country, marked by a general strike of the public sector that included most institutions of higher education. This unrest limited access to faculty members and students who had deserted the universities. The ongoing strikes and resultant socio-economic strain on civil servants and state officials made it challenging to schedule interviews with government authorities. Finally, a complete reshuffling of the government took place during this study, which redirected some aspects of the research and yielded intriguing results but limited the ability of the authors to meet with some of the government personnel whom the team planned to interview. Although these developments undoubtedly affected the results, the findings of this research brief nevertheless offer pertinent insights into debates on secularism in higher education in Chadian contexts and their implications for $\mathrm{P} / \mathrm{CVE}$ policies and practice.

\footnotetext{
${ }^{8}$ This research was approved through Solutions IRB under the generic protocol document: \#2018/02/13, "The Politics of Religion, Higher Education, and the State: A Study of Chad.”
} 


\section{Context}

\section{CONFLICT AND VIOLENT EXTREMISM IN CHAD}

Chad is a multi-religious, multicultural, and multilingual country with more than 100 distinct ethno-linguistic groups. ${ }^{9}$ Three major types of religions coexist in the country: Islam, Christianity, and traditional religions. The majority of Chadians ( 58.4 percent) profess to follow Islam, while a sizeable minority identifies as Christian (34.6 percent). ${ }^{10}$ In practice, living together has not always been easy.

Chad's history of civil war and violent conflict left its society deeply divided and sowed suspicion among many of its different social groups. Following independence from France in 1960, the country plunged into decades of violence and civil war as rival armed rebellions broke out in efforts to capture control of the state. The country remained embroiled in civil war until 1982, when Hissein Habré came to power. Habré's reign was characterized by a bloody dictatorship that took the lives of at least 400,000 people over eight years. ${ }^{11}$ In 1990, Idriss Déby overthrew Habré's regime and has managed to maintain power ever since. Under Déby, a political transition ushered in nominally democratic institutions - namely, multiparty elections - and relative political stability. Still, issues related to governance and the spillover from conflict dynamics in the Central African Republic and Libya continue to threaten the stability of the country.

Social divisions and conflict in Chad remained after the political transition to Déby. Today, social fragmentation in the country often leads to conflict, especially in cases where certain groups receive, or are perceived to receive, preferential treatment from the state. Identity markers related to ethnicity, religion, or regional background are regularly manipulated to stoke socio-political tensions and foster mistrust between citizens and communities. Similarly, in the public sphere and in political debates, religion remains a persistent variable. Recent debates around the new constitution and the addition of a confessional oath of office have exacerbated this situation. ${ }^{12}$ Unlike certain ethno-regional animosities, however, acts of inter-religious violence have and continue to be rare throughout the country, albeit with a few exceptions. ${ }^{13}$

While inter-religious violence remains low at present, Boko Haram's rhetoric against secular institutions and presence in northeastern Nigeria and around Lake Chad continues

\footnotetext{
${ }^{9}$ Jean Chapelle, Le peuple tchadien: Ses racines, sa vie quotidienne et ses combats, (Paris: L'Harmattan,), 1986), 39; M. Paul Lewis, ed., Ethnologue: Languages of the World (Dallas: SIL International, 2009).

${ }^{10}$ For the most demographic information from the census conducted in 2009, see: INSEED, Deuxième recensement général de la population et de l'habitat (RGPH2, 2009); Résultats globaux définitifs. (N’Djamena: INSEED, 2012).

${ }^{11}$ Mahamat Hassan Abakar. 2006. Chronique d'une enquête criminelle nationale: le cas du régime de Hissein Habré, 1982-1990, (Paris: L'Harmattan, 2006, 70); Celeste Hicks, The Trial of Hissene Habre: How the People of Chad Brought a Tyrant to Justice, (Chicago: University of Chicago Press, 2018).

${ }^{12}$ As discussed later in this brief.

${ }^{13}$ See AFP, “Tchad: 72 morts lors de l'arrestation d'un 'gourou' jihadiste,” 2008; N'Djaména-Hebdo, « La communauté musulmane du Tchad organise une manifestation le février 11, 2006: jets de pierre sur les écoles catholiques ", N'Djaména-Hebdo n929, Janvier 2, 2006 ; Remadji Hoinathy, « Études des perceptions sur les facteurs de l'insécurité et de L'extrémisme violent dans les régions frontalières du sahel, « Ce que disent 698 sahéliens ». Rapport National Tchad, (HD-PNUD, 2015, 11); and Remadji Hoinathy and Sally Bakari, «Le djihad du Cheikh Ahmat Ismael Bichara à Kouno, Tchad», in Mirjam de Bruijn, Biographies de la Radicalisation, (Oxford: African Books Collective, 2018, 59-74).]
} 
to aggravate relationships among different religious communities in Chad. ${ }^{14}$ The rise of Boko Haram in the Lake Chad Basin and Chad's subsequent war against the group has alarmed many Chadians, who are concerned about violent extremism in the country and a possible return of violent conflict. Although Chad has not been subject to as many attacks as have Cameroon, Niger, or Nigeria, recent research demonstrates that rampant stigmatization along both religious and ethnic lines may increase vulnerabilities to the actions of Boko Haram. ${ }^{15}$ Fears of particular religious groups aligning their ideological and political motivations with Boko Haram or similar groups have rekindled concern over the role of religious leaders professing to follow a Wahhabi or Salafist interpretation of Islam in the public sphere. These dynamics have tangentially sparked debate over the secular nature of the Chadian state. The limited evidence to date suggests that the lack of access to central state apparatuses and services has contributed to support for and recruitment into Boko Haram among Chadians living in outlying and impoverished Lake Chad island communities. ${ }^{16}$

\section{CONNECTIONS TO HIGHER EDUCATION: SECULAR DIVIDES}

Research on violent extremism and higher education in general is somewhat limited throughout the Lake Chad Basin, and particularly in Chad. Studies that do exist have focused on the increasing role of religion and religious instruction in Lake Chad Basin university settings. However, those studies do not provide sufficient evidence to determine what relationship that trend may have, if any, on the spread of violent extremist groups like Boko Haram. Such studies also lack insights into how different dynamics and policies have impacted debates and conflicts over religion on campuses. ${ }^{17}$ While increasing religiosity in higher education should by no means be equated with increasing support for or inclination to violent extremism, it is important to understand how the increased demand for religious representation on campus is being negotiated by different religious and non-religious actors in government, on campus, and in local communities.

In a country like Chad, which officially adheres to laïcité - a strong version of secularism based on French legal tradition - social divisions reducing resilience to conflict and violent extremism may deepen if debates over the place of religion in the public sphere and grievances related to perceived preferential treatment for some groups appear to be increasing. ${ }^{18}$ As such, analyzing the ways in which the understandings of laïcité and religion are shaped and transformed through the constant bricolage of institutional norms and policies — including those governing higher education — and the extent to which campus dynamics have any impact on, or are impacted by, violent extremism in the region constitutes an important objective for P/CVE actors.

\footnotetext{
${ }^{14}$ For more information on Boko Haram in the Lake Chad Basin, see: G. Magrin and Marc-Antoine Pérouse de Montclos, Crise et developpement: la région du lac Tchad à l'epreuve de Boko Haram (Paris: AFD, 2018).

${ }^{15}$ Magrin and Pérouse de Montclos (Paris: AFD, 2018), 200.

${ }^{16}$ Ben Taub, "Lake Chad: The World's Most Complex Humanitarian Disaster," The New Yorker, December 4, 2017; https://www.newyorker.com/magazine/2017/12/04/lake-chad-the-worlds-most-complex-humanitarian-disaster.

${ }^{17}$ Alexander Thurston, 2018.

${ }^{18}$ Centre Al Mouna, “Quelle laïcité pour un Tchad pluriel? ”, in Al-Mouna, Quelle laïcité pour un Tchad pluriel ?, (N'Djamena : Centre Al-Mouna, 2000), 7-8.
} 


\section{Secularism and the Politics of Religion in Chad}

The Chadian constitution, taking into account the country's diversity, has always consecrated the unified will of the nation's diverse populations and enshrined a secular, or laï, form of the state. The preamble to the most recent constitution, drafted on March 4, 2018, and adopted by the National Assembly on April 30, 2018, reconfirmed the country's commitment, in principle, to diversity and secularism. ${ }^{19}$ However, while secularism is generally regarded as a means by which to prevent discrimination on the basis of religion, it risks being perceived as exclusionary, anti-religious, or biased, depending on its implementation. ${ }^{20}$

Divergences in perceptions and experiences of secularism within Chadian communities, coupled with Boko Haram's anti-secular and anti-Western education rhetoric, have made understanding the ways in which secular policies are crafted and implemented all the more important as the country's system of governance continues to evolve. As scholars pointed out almost two decades ago, perceptions of secularism in Chad vary significantly — "to some people, laïcité represents the gate to atheism, [while] for others, it represents the last rampart against Islamism." 21 As such, "laïcité is charged with the passions, worries, interrogations, and hope" of everyday Chadians." 22

According to statistics from 2015, the number of students enrolled in public and private universities is relatively low. ${ }^{23}$ Low enrollment can be explained in part by Chadian students' propensity to travel abroad for higher education. Students regularly travel abroad to other sub-Saharan African countries - such as Benin, Cameroon, Ghana, Nigeria, Senegal, Sudan, and Togo - for higher education studies. Student also frequently travel to the Maghreb, especially Algeria and Morocco; the Middle East, particularly Saudi Arabia; and Europe, particularly France. The austerity measures introduced over the past two years by the Chadian government exacerbated strikes within the public sector and increased the desire of students to study abroad. Pursuing studies abroad, however, remains an option limited to those who can afford it. In Chad's higher education sector, which is governed by the principle of laïcité, leaders have a key role to play in the interpretation and understanding of the secularism to which the state adheres and in the debates over the place of religion in the public sphere. These interpretations are undoubtedly shaped in

\footnotetext{
${ }^{19}$ The preamble of the current constitution reads, "to live together with respect for ethnic, religious, regional and cultural diversities; to build a rule of law and a united nation based on public freedoms and fundamental human rights, the dignity of the human person and political pluralism, on the African values of solidarity and fraternity." Article 5 of the constitution further clarifies, "any propaganda of an ethnic, tribal, regional or confessional nature tending to undermine national unity or the secularity of the State is prohibited."

${ }^{20}$ See Hussein Ali Agrama, Questioning Secularism: Islam, Sovereignty, and the Rule of Law in Modern Egypt (Chicago: University of Chicago Press, 2012); Talal Asad, Genealogies of Religion: Discipline and Reasons of Power in Christianity and Islam (Baltimore, MD: Johns Hopkins Press, 1993); Timothy Fitzgerald, "Encompassing Religion, Privatized Religions and the Invention of Modern Politics," in Timothy Fitzgerald (ed.), Religion and the Secular: Historical and Colonial Formations (London: Routledge, 2007).

${ }^{21}$ Centre Al Mouna 2000: 7

${ }^{22}$ Gali Ngothé Gatta, «Histoire et cadre juridique de la laïcité. », in Centre Al-Mouna (ed.), Quelle laïcité pour un Tchad pluriel ?, (Centre Al-Mouna, 2000), 11-20.

${ }^{23}$ An estimated 33,110 (6,201 female) Chadians were enrolled in public higher education institutions and an estimated 7,639 $(2,809$ female) in private institutions, for a total of 40,749 Chadians enrolled. For more information, see: Ministry of Higher Education 2017.
} 
some ways by the higher education that Chadian intellectuals and elites receive. Efforts to address these issues and strengthen inter- and intracommunal ties and resilience are needed, given the nature of these debates, the conflicts that may arise, and the unapologetically anti-secular stance of violent extremist groups like Boko Haram.

\section{SECULARISM IN CHADIAN HIGHER EDUCATION: A RIFT BETWEEN POLICY AND PRACTICE}

According to Article 38 of the March 4, 2018, Constitution, "every citizen has the right to an education. Basic public education is secular and free." Charged with upholding this provision, Chad's Ministry of Higher Education, Scientific Research, and Innovation (henceforth referred to as the Ministry of Higher Education) regulates all public and private institutions of higher education - whether universities, colleges, or institutes. ${ }^{24}$

A secular institution, the Ministry of Higher Education maintains significant influence over the higher education system. In addition to regulating institutions, the Ministry also oversees and awards all bachelor's and master's degrees. Two doctoral programs established in N'Djamena in 2017, also regulated by the Ministry of Higher Education, serves all universities in the country and will enable students to obtain their doctorate degrees. ${ }^{25}$

Over the years, the higher education sector in Chad has gradually expanded, offering more opportunities for potential students. For several decades, higher education in Chad was limited to the University of Chad (now the University of N'Djamena) and its two campuses in N'Djamena: (1) Ardep Djoumal, dedicated to human sciences, management, and law; and (2) Farcha, responsible for instruction in the hard sciences. Created in 1971, this university aimed to educate young Chadians who aspired to be leaders in the development and governance of the state. Beginning in the 2000s, however, other universities and institutes began to open. Today, Chad has eight different public universities in Ati, N'Djamena, Abeché, Doba, Mongo, Moundou, Pala, and Sarh. In 2014, the government opened an additional University of N'Djamena campus in Toukra on the outskirts of N'Djamena. In addition to these universities and campuses, Chad has seven institutes and four teacher training colleges, all of which are under the administration of the Ministry of Higher Education. There are also some private universities and institutions of higher education, namely, Emi Koussi University, Francophonie University, and the Hautes Etudes Commerciales Tchad. URF was one of the first private universities of the country; unlike the others, it is an Arabophone university that was originally hosted at the central mosque of N'Djaména. Today, URF is a semi-public university; the state provides support and some administrative supervision and regulation.

Despite the constitutional provision and the Ministry's authority, however, the extent to which principles of secularism are upheld in practice within the higher education system varies. Non-state actors, like the CSAI and the ISESCO, represent important actors in this

\footnotetext{
${ }^{24}$ During the research conducted for this research brief, we focused on the main universities in N'Djamena that are public institutions. As a semi-public university, URF receives support from the Ministry of Higher Education but is also governed by the administration of the CSAI. ISESCO is a teacher training institution and so not technically a university; however, its direct contributions to educating future educators warranted attention for this research brief.

${ }^{25}$ One is in technical science and environment, and a second is in humanities and social sciences.
} 
context; such actors wield significant influence over the extent to which religious content is represented in higher education curricula and institutions that are otherwise secular in nature.

CSAI, for example, has had a significant impact on higher education in Chad, specifically on UFR. A non-state organization with responsibility and oversight over Islamic activities in Chad, CSAI is responsible for religious activities ranging from providing Islamic instruction, to coordinating and representing Islamic organizations and activities domestically and internationally, to developing the Arabo-Muslim culture and Arabic instruction in the country. ${ }^{26} \mathrm{CSAI}$ 's influence reaches into the higher education system, where it oversees and shapes coursework in Arabic. This institution used to directly supervise URF in N'Djamena (discussed further in the next section).

Similar to CSAI, the ISESCO exerts significant influence over higher education in Chad. ISESCO - an international Islamic institute to promote education, science, culture, and communication as a means of contributing to the Islamic world and the development of human civilization - established a regional pedagogical center in Chad in 2011 and maintains it today. The regional office in Chad coordinates activities in 11 countries, including Benin, Burkina Faso, Cameroon, Coté d'Ivoire, Mali, Niger, Nigeria, and Togo. In Chad, ISESCO offers training and instruction in Arabic for Chadian administrators and executives - especially those with a francophone education - to support bilingualism in the country. ISESCO also trains and supervises Arabic-speaking teachers by organizing approximately seven training sessions annually. For teachers, the program includes classic academic subjects, such as mathematics, literature, history, and geography, as well as environmental, life, earth, and computer sciences. The training includes pedagogical approaches that address different techniques for how to teach these subjects. Teachers and students of ISESCO also receive instruction in Islamic teachings.

The extent to which both organizations and their influence on the nature of higher education in Chad - particularly over content and responsibilities otherwise considered non-religious in nature, including Arabic language instruction, university supervision, and teacher training - is significant depends in large part on how their involvement is perceived to be complementary or in opposition to the secular principles guiding state policies.

\footnotetext{
${ }^{26}$ For further information on CSAI, see: https://berkleycenter.georgetown.edu/organizations/high-council-for-islamic-affairs.
} 


\section{Findings}

Although the Chadian state and higher education sector are built around the principles of secularism, the extent to which the definition of secularism is contested and the extent to which religious organizations exert influence over higher education constitute important, yet understudied, dynamics. Understanding how these dynamics are perceived and how they impact relationships between communities on and off campus is particularly relevant to understanding potential resiliencies, vulnerabilities, and interventions to prevent and address violent extremism society-wide. Following on RESOLVE's "Campuses and Conflict" report, findings in this research brief probe the ways in which universities due to their religious orientation, attendance, and curricula - may develop into secular or non-secular environments. The brief further considers how these perceptions contribute to increasingly polarized positions toward the acceptance or rejection of a multi-religious society and the subsequent implications for policy and practice.

\section{VIOLENT EXTREMISM AND CONFLICT ON CHADIAN CAMPUSES: AN UNLIKELY THREAT}

As in Cameroon, ${ }^{27}$ research conducted for this research brief found little evidence of violent extremism or support for it among key stakeholders in the Chadian higher education system. This finding may be unsurprising, given that enrollment in higher education in Chad is relatively $\operatorname{low}^{28}$ and that evidence indicates that Boko Haram's presence in Chad is largely outside of population centers. Moreover, those who do attend higher education institutions have usually set their sights on becoming a part of the existing state structures and have little motivation to wholly reject and overthrow it.

Still, debates about the secular character of the state and the role of religion in the public sphere reveal important socio-religious divisions in higher education. If left unaddressed, these divisions, coupled with other social grievances and the adverse impact of recent austerity measures, could result in increased social polarization that could undermine the resiliency of Chadian society to the actions of violent extremist actors such as Boko Haram.

\section{PERCEPTIONS OF SECULARISM ON CAMPUS}

To better understand issues surrounding secularism and its role in producing expectations and/or frustrations conducive to the rise or mitigation of violent extremism, research conducted for this brief sought to first understand the varied conceptions of secularism among higher education regulators and student populations. At a fundamental level, individuals interviewed for this study conceived of secularism as a "separation of religion and the state," ${ }^{29}$ that is, "the state is situated at an equal distance between religions.

\footnotetext{
${ }^{27}$ Brandon Kendhammer and Adama Ousmanou, "Islam, Higher Education, and Extremism in Cameroon: Lived Experiences and Campus Dynamics," RESOLVE Network Lake Chad Basin Series Research Brief no. 1, December 2018.

${ }^{28}$ According to a 2015 United Nations study, Chad's higher education enrollment rate is less than 4 percent. See: UNESCO, "Gross Enrollment by Level of Education," http://data.uis.unesco.org/index.aspx?queryid=142.

${ }^{29}$ Focus group with students from URF, March 29, 2018.
} 
Religion becomes a private affair and the state regulates [public life] in coexistence with religions." ${ }^{30}$ Virtually all of our respondents accepted this basic formulation, but when probed further, their definitions proved more diverse. As one respondent asserted, "here in Chad, secularism is not understood in the same way by everyone." 31

For some, the very character of Chad's multi-religious society underscores the need for a strong secular system. Secularism, at least in theory, enables the peaceful coexistence of Chad's different religious communities, its raison d'être. In the words of one focus group participant, "[secularism] thus becomes a necessary order dictated by the socio-cultural composition of the country." ${ }^{2} 2$ Nearly all non-Muslim participants and several Muslims respondents shared this conception.

Others, however, questioned secularism's appropriateness by highlighting its foreign origins. Students at URF ${ }^{33}$ notably agreed with this view, demonstrating strong opinions on secularism. Although these students accepted secularism in principle, they expressed the view that its application in Chad only takes place to comply with Western dictates and customs. Other Muslim intellectual and scholars share this view: “(...) this laïcité has been bluntly imposed in Chad and resulted in an exclusion of Islam, which is not a religion from France." 34 In the words of one male Muslim student, "secularism certainly means the separation of religion from the state, but can the state function without religion? The separation of religion from the state is a Western vision." ${ }^{35}$ Secularism, for some, accordingly presents an avatar of Western colonization, a foreign imposition, which even the socio-anthropological composition of Chad cannot justify. This view led some Muslims interviewed to conclude that Muslims should not accept secular policies, and they criticized Chadian political leaders for maintaining this colonial artifact. As one respondent noted, "We should not separate the state from religion. France and other nonMuslim countries should apply secularism. This policy of secularism was imposed on us by colonization. Unfortunately, our leaders follow [it] like tails." ${ }^{\prime 36}$

Arguments such as this, clearly opposed to the principle of secularization, hinge on the view that secularism is equivalent to the "sanitization" of the public sphere from faith and worship as exemplified by the Western world. In opposition to this notion of secularism, many respondents suggested that Islam does not provide such an aseptic vision of the public sphere and accordingly is incompatible with secularism. As one respondent expressed, "some say that secularism is not in accordance with Islam because this religion organizes all spheres of life." 37 This view was substantiated by the relatively clear rejection of secularism among some of the Muslim focus group participants.

Still, and even paradoxically, several other Muslim participants offered an alternative perspective. This perspective was captured well in an interview during which the leader of

\footnotetext{
${ }^{30}$ Interview with a secondary school teacher researcher on Islam in Chad, February 26, 2018.

${ }^{31}$ Interview with a leader of a civil society organization focused on peace building, February 26, 2018.

${ }^{32}$ Focus group with students from URF, March 29, 2018.

${ }^{33}$ A decidedly Muslim institution discussed in subsequent sections of this brief.

${ }^{34}$ Abazene Seid. « Islam et laïcité. » in Quelle laïcité pour un Tchad pluriel ? (N’Djamena: Centre Al-Mouna, 2000), 35-51.

${ }^{35}$ Focus group with students from URF, March 29, 2018.

${ }^{36}$ Focus group with students from URF, March 29, 2018.

${ }^{37}$ Interview with a member of a civil society organization, February 27, 2018.
} 
an Arab-Muslim cultural center recognized that "secularism even exists in the constitution, and [public] education should be secular. We should be secular as well in our everyday behaviors. In our institutions everything is bilingual, and everyone should practice their religion in the private sphere." ${ }^{38}$ Within the Chadian Muslim community, citizens hold several contrasting views on the role and place of religion in public life. These views are at times consistent with the legally enshrined version of laïcité; at other times, they are in direct conflict with such an interpretation. However, the boundaries of the religious and public spheres remain persistently ambiguous.

The high degree of ambiguity surrounding the perceptions of and attitudes toward the appropriate boundaries of public and private spheres presents certain dilemmas and challenges to policy and practice within the Chadian state. ${ }^{39}$ Accordingly, many of those interviewed expressed growing concerns about certain obstacles to secularism in the country. These concerns centered on their fears that secularism as a principle has been increasingly challenged; if the contestation continues, it may lead to violent confrontation. As we discuss in the following section, even the state finds it difficult to position itself regarding its secular agenda, tilting to one side or the other, depending on pressures from different actors. Mirroring findings in Cameroon, some respondents seemed to consider secular policies as simply another means for the state and other actors to exert power over religious actors and behaviors through the use of religious symbols, actors, and behaviors. ${ }^{40}$ As one respondent reflected, "It is all about power. People are trying new things, and if there is no enforcement to keep religion in the private sphere, [religion in the public sphere] can go further." ${ }^{11}$ The boundaries of the public and religious spheres may be welldefined in the constitution and other juridical documents; however, like much of Chadian society and politics, the actual application of those boundaries is undergoing a constant reconfiguration. In Chad's public system of higher education, the impact of this disparity in policy and practice is significant, given the divisions it engenders between different religious student populations in terms of opportunities and instruction. Two areas where the lines between the secular nature of public higher education and the religious influence within it are particularly clear are language and religious-leaning institutions.

\section{LANGUAGE AND RELIGION: SEPARATE AND OVERLAPPING}

In accordance with Chadian law and official policy guiding education, public universities — as well as primary and secondary schools — are bilingual and, as public institutions, secular. Religious instruction, religious training, or essentially even references to religion within these public spaces are forbidden by law. Accordingly, in principle, religious instruction falls outside of the purview of the Ministry of Higher Education and public universities. In practice, however, certain aspects of the higher education system blur these boundaries in specific venues. Language divisions frequently correspond to or overlap with the religious identifications of students. Moreover, the extent to which

\footnotetext{
${ }^{38}$ Interview with a manager of an Arab-Muslim cultural center, February 27, 2018.

${ }^{39}$ Such diverse positions are increasingly common in Chad and elsewhere. See, for example: Sounaye, 2009.

${ }^{40}$ Kendhammer and Ousmanou, "Islam, Higher Education, and Extremism in Cameroon."

${ }^{41}$ Interview with a secondary school teacher researcher on Islam in Chad, February 27, 2018.
} 
religion is embedded in instruction provided in each of the languages poses a further challenge.

In Chad, the official bureaucratic languages, and thus the two official languages for education and teaching, are Arabic and French. Arabic — or rather, Chadian Arabic, a spoken Arabic dialect sometimes referred to as Shuwa Arabic — serves as a lingua franca spoken virtually throughout the entire country. However, much like elsewhere, despite the pervasiveness of Chadian Arabic, classical literary Arabic or Modern Standard Arabic is the official language recognized by the state and taught in formal settings. While French has been the primary language of instruction in public universities and schools for decades, Arabic has gradually risen in usage in educational settings.

French, the language of former colonial authorities, and Modern Standard Arabic are both foreign languages in Chad. Historically, French language benefited from the close ties maintained between the governments of France and newly independent Chad. French also dominated the administrative and educational sectors before Arabic; at the time of independence, most Chadian officials had been trained in France or other Western countries. However, after independence, Chadian elites increasingly began to attend universities in the Middle East. This shift started balancing the debate on bilingualism in the country; "in an attempt to re-equilibrate, Arabic was adopted in 1982 as the second official language." ${ }^{42}$

Over time, this debate transformed as it developed a high degree of symbolic violence. Indeed, "behind the debate on the respective place of French and Arabic in the country lay societal choices, obedience, and a fight for power, in which denominational references were invoked for better and for worse." ${ }^{43}$ The question of the secular nature of the state, particularly within the sphere of higher education, risks reopening this debate in contemporary Chad, and may, in turn, foment tensions between religious groups.

The division between the two languages is important, particularly because of how it overlaps with religious divisions and curricula. In Chad, the baccalaureate is the last diploma conferred on students who complete their secondary education. It opens the door to public or private university education; because of this, university administrators ensure that students meet the standards of compliance for the baccalaureate. However, in practice, primary and secondary education is not absolutely secular. French-speaking and Arabic-speaking primary and secondary schools are often religious in nature. In the case of primary madrassas, Arabic-speaking public schools, the curriculum includes compulsory teaching of the Koran, hadith, and other Islamic texts. In the past, these religious subjects were tested and graded as a component of the Arabophone baccalaureate examinations. Requirements such as this necessitated religious knowledge to be able to pass Arabic baccalaureate examinations, potentially precluding non-Muslims who were pursuing Arabic studies from passing.

This situation changed in 1991. The Minister of Education abolished the religion test of the baccalaureate, since it is a public diploma administered by an officially secular country. Predictably, this change produced an outcry among Muslim communities, especially within

\footnotetext{
${ }^{42}$ Henri Coudray, « Langue, religion, identité, pouvoir: le contentieux linguistique franco-arabe au Tchad,» in Contentieux linguistique arabe-francais, (N'Djamena: Centre Al-Mouna, 1998): 19-65, 19-20.

${ }^{43}$ Ibid.
} 
certain fundamentalist circles. ${ }^{44}$ To calm this unrest, school administrators proposed an intermediate solution; they would maintain the test and report it on the transcript, but the examination was to be treated in such a way that it had no effect on the final evaluation of the students.

Nevertheless, the impact of the extent to which religious instruction and language instruction are intertwined is felt within higher education today. In almost all public universities, language bifurcates academic departments. For example, in the College of Humanities and the Social Sciences, there are both a Francophone department of history and an Arabic department of history. These departments have different faculty members who offer different courses based on the language used by the instructor. As a result, the curricula also differ significantly in terms of how religion and religious debates are integrated into the course content. Students registered in Arabic-speaking departments are almost exclusively Muslim, while those registered in French-speaking departments tend to be non-Muslim or religiously mixed. Similarly, teachers of the respective departments tend to belong to the corresponding religious traditions.

Further, research conducted for this brief revealed that it is common for Arabicspeaking teachers - in university settings and in primary and secondary schools to begin the courses with religious benedictions. As one respondent noted: [In Chad] teaching in Arabic is semi-equivalent to teaching Islam because from the first course students take, instructors write 'Bismillahi-r-Rahmani-r-Rahim, ${ }^{45}$ and there is no Arabic language school without religious content. This formula is repeated on the heading of academic documents, such as books and transcripts. ${ }^{46}$

Another respondent maintained, "On the issue of bilingualism, we must relativize the debate. Teachers' backgrounds make them begin each teaching with 'Bismillahi-rRahmani-r-Rahim,' which is a religious formula. Despite the secular vocation of schools, teachers do what they want." ${ }^{\prime 7}$ Observations such as these were repeated in multiple interviews and substantiated by students.

Thus, the relationships between religion and language, especially the Arabic language and Islam, are particularly murky with respect to the maintenance of secular classrooms. This language is the language of the Koran, but it also a language of communication, science, and therefore, teaching. In principle, then, it can be used independently of religion. In practice, all universities should offer courses in Arabic for all those seeking to master the language, given the official bilingual status of the Chadian state, without religious requirements. Ideally, these courses would be available even outside of the Arabic-speaking departments.

\footnotetext{
${ }^{44}$ Mostly associated with Ansar al-Sunna. For more details, see: Remadji Hoinathy, 2015, 13.

${ }^{45}$ The phrase "Bismillahi-r-Rahmani-r-Rahim" can be interpreted as "in the name of God, the gracious, the merciful" and is routinely uttered at the beginning of religious and non-religious events and ceremonies in Muslim society.

${ }^{46}$ Interview with a secondary school teacher researcher on Islam in Chad, February 26, 2018.

${ }^{47}$ Interview with a teacher-researcher from the École Normale Supérieure, February 27, 2018. These activities were repeated in multiple interviewees and substantiated by students. The question is to what extent the state should play a role in regulating these matters. An interesting counterfactual might consider the actions the state would take if a Christian teacher began each class with a reading from the Bible.
} 
Unfortunately, this is not currently the case. Instead, university departments are split between the French-speaking and Arabic-speaking instructors who operate side by side, sometimes with very different curricula. In practice, the departments are separated and independent; even though they are under the authority of the same dean. Frequently, each department has two distinct department chairs, an arabophone chair and a francophone chair. This organizational model has had an impact on the principles of secularism as described by our study participants. Secularism is considered good in principle but not in practice. It remains unacceptable to many Muslim instructors teaching in Arabic; consequently, many Christians and non-Muslims perceive secularism as superficially implemented by the current Chadian state. These perceptions among educators and administrators only further deepen the divisive potential of the current bilingual frameworks operating in the domain of higher education.

Several implications can be drawn from these observations. Practically, the ability to advance one's career working under a dean or chair who is only fluent in one language may depend in part on working in the same language. Advocating for the complete secularization of higher education curricula risks alienating many Arabic-speaking instructors, department chairs, and deans. It may also serve to further divide the student body along religious lines. As highlighted by our focus group discussions, some students view the anti-religious nature of laïcité in the classroom as unnecessary and culturally alien to their social norms. Yet, the incorporation of Islamic teaching and customs through the use of the Arabic language in the classroom also risks alienating non-Muslim faculty members, administrators, and students. These forms of alienation pose a potential risk of leading to increasingly extremist debates about the place of religion in public schools. If such debates continue to foster divisions within religious communities, these divisions could undermine the resiliency of university campuses and broader society to conflict and efforts undertaken by violent extremists. Given its divisive impact, the regulation of the bilingual education system and the role of language as a religious element are important areas of consideration for those looking to design efforts to build social unity and resiliency in Chad.

Moving forward, important questions for policymakers and practitioners to consider include the following:

- The extent to which the state should play a role in regulating the use of religious materials in language curricula.

- The way religiously inclined schools teach Arabic may deprive non-Muslim students of higher education opportunities and thereby elevate grievances.

- Opportunities for education in Arabic and French that are perceived by students to be less influenced or less defined by religion.

- Opportunities for increased engagement between French- and Arabic-focused students and faculty. 


\section{INSTITUTIONS OF HIGHER EDUCATION: BLURRING THE LINES BETWEEN RELIGION AND SECULARISM}

Issues associated with the religious nature of language instruction and curricula in higher education systems are also reflected within certain institutions that operate within the secular higher education sphere but have a notable religious tilt. Research conducted for this research brief focused on two such higher education institutions that stand out as having particular religious leanings and influence: URF and ISESCO. Probing the implications of this finding, the research revealed interesting dynamics related to disparities in opportunities, divisions, and vulnerabilities that these institutions, which are secular in name but not in necessarily in practice, have engendered.

\section{KING FAYÇAL UNIVERSITY: AN ISLAMIC ARCHIPELAGO?}

Located in the capital city of N'Djamena, URF is a premier institution known for training Chad's Muslim elite. URF holds a unique position among the public universities because of its overlapping oversight by both the Ministry of Education and the CSAI, the Islamic organization responsible for regulating and overseeing Islamic activities and relations in Chad. As a result, it assumes its status as a Muslim university in clear opposition to the otherwise secular policies that govern public higher education institutions; it does so despite its status as a semi-public education institution. In several discussions, respondents suggested that, although technically secular in nature, URF is a Muslim institution for the education of Muslim students by Muslim professors; as such, non-Muslim students either do not want to attend URF or are unable to do so, given the religious course requirements for entry. One interviewee noted, "No non-Muslim thinks to register with URF for fear of being discriminated against or converted to Islam." 48 This situation is problematic because, as a form of self-selection, such dynamics can deepen the anti-associational aspects of Chad's current educational system and exacerbate grievances between Muslim and nonMuslim groups. Moreover, URF's requirements for entry include specific knowledge of religious curricula, which means that even students from similar Arabic-speaking departments at the University of N'Djamena may not be able to transfer to or attend URF because they lack the requisite religious courses. As one interviewee pointed out: "At the University of N'Djamena, students earn the Arabic Living Language [degree] with the history of civilization and Arabic syntax. However, in the 3rd year when they intend go to King Fayçal for the[ir] master['s], they must resume with the religious subjects and be evaluated [on those materials] first." 49

URF's relation to the construction of a bilingual, but secular, Chadian nation remains ambiguous at best. Despite its now semi-public university status, URF appears to approach such a status with an indifference to secular and equal training. This approach, in turn, as revealed during research conducted for this research brief, creates a kind of exclusionary atmosphere, precluding some from attaining the connections and education that URF provides.

\footnotetext{
${ }^{48}$ Interview with a member of a civil society organization.

${ }^{49}$ Interview with a secondary school teacher researcher on Islam in Chad.
} 
ISESCO's Educational Centre in Chad was established in line with ISESCO's global efforts to "devise plans and support the appropriate projects in order to develop Islamic culture and publicize it, and to disseminate the teaching of Arabic to non-Arabic speakers all over the world, being the language of the Holy Quran." ${ }^{50}$ However, as a provider of higher education in the country, ISESCO falls under the supervision of the Ministry of Higher Education. As mentioned, among its other activities, ISESCO's Educational Centre in Chad provides Arabic language instruction to the public and to teachers in bilingual schools. An agreement signed with the Chadian government enables the Educational Centre to train teachers at a level equivalent in ranking to those trained in public teachers' training schools, ensuring that the ISESCO-trained teachers are accepted into the civil service on the same basis. However, unlike the curriculum of most teacher training schools, ISESCO employs didactic aspects from Islamic education.

Teachers trained by ISESCO are made available to public schools and Muslim schools. Here, too, the religious agenda raises questions. Are the Ministry of Higher Education and the Ministry of Education directly contributing to the training of teachers who incorporate religion into the national curriculum? If this is the case, again, the blurred boundaries of language and religion result in an ambiguous form of secular education at best. The potentially divisive and grievance-inducing effects of these blurred boundaries should be noted. The introduction of religious teachings into the curricula of education is often taken for granted within the contexts of Arabic instruction. Yet, an equivalent form of religious instruction appears to be lacking in the Francophone, secular contexts.

In the opinion of some of our study participants, introducing religious teachings into educational curricula responds to the real needs on the ground for religious education within [predominantly Islamic] educational institutions in order to inculcate more morale and life skills to students. ${ }^{51}$ In the words of one interviewee, and in line with dynamics noted in previous research, "Islamic education in schools responds to a real need expressed by Muslim parents." ${ }^{53}$ Islamic education may also speak to a wider form of cultural exposure that often accompanies language training. Several cultural centers in Chad from Arabicspeaking countries work to reinforce Arabic language and culture. ${ }^{54}$ In this sense, these cultural centers support Arabic language training; at the same time, "they state that one cannot learn Arabic very well without the Koran." ${ }^{55}$ This attitude may explain the perceived importance of religious alongside educational training, but it overlooks the impact that such religious incorporation has for the larger Chadian community. Importantly, it also appears to stand in stark contrast to the stated responsibilities of the state.

\footnotetext{
${ }^{50} \mathrm{https}: / /$ www.isesco.org.ma/isesco-centres/.

${ }^{51}$ This view emerged in several interviews.

${ }^{52}$ Alexander Thurston, 2018.

${ }^{53}$ Interview with a secondary school teacher researcher on Islam in Chad.

${ }^{54}$ In future research, we hope to investigate the roles of both Arabic-speaking and French-speaking cultural centers to better understand the influence of foreign actors in these debates.

${ }^{55}$ Interview with a manager of an Arab-Muslim cultural center.
} 
The divisions created by the blurring of secular and religious lines in institutions of higher education such as ISESCO and URF merit specific considerations for policymakers and practitioners, including:

- Crafting interventions and policies that address the needs of both Muslim and non-Muslim student populations and communities without having exclusionary or divisive impacts.

- Fostering opportunities for increased engagement between Muslim and non-Muslim populations. 


\section{Enduring Issues: The Chadian State, Secularism, Religion, and Higher Education}

While this research brief found little evidence suggesting that violent extremism is a present threat on Chadian university campuses, continued religious influence in the otherwise secular higher education system in Chad and the grievances and disparities it provokes remain pressing concerns. Particularly problematic are the implications that the continued erosion of secular principles, including those guiding the higher education sector, may have on increasing social polarization and decreasing social cohesion and harmony in Chad. Recent debates and reforms related to secularism on the national level reveal the importance of further attention from policymakers and practitioners.

\section{EVOLVING DYNAMICS AROUND RELIGION, SECULARISM, AND THE STATE}

During this research, the Chadian government announced and organized an inclusive national forum to draft a new constitution. The actions of the government at the time of writing revealed a tacit, although perhaps inadvertent, policy framing that diminishes the secular nature of the state. This approach may present or signal an opportunity for those seeking to promote violent extremism in the public sphere. As the government and state become more involved in religious affairs, or as public life becomes increasingly tinged by a particular religious system, certain religious groups are more likely to feel excluded by the state. This process may, in effect, deepen social divisions and undermine community dynamics in higher education and in the broader population. The erosion of secular principles during the national forum and the subsequent actions of the government following the adoption of the new constitutions are worrisome. To regulate the role of religion in the public sphere, the state should maintain a neutral disposition toward all religious belief systems. The extent to which these reforms would affect not only the everyday lives of Chadian citizens, but also the politics of religion on university campuses and prospects for employment following graduation, has significant implications. These include the potential to exacerbate nascent tensions and grievances among disaffected populations on campuses and beyond.

The national forum proposed to reform the constitution and Republic of Chad across six themes. ${ }^{56}$ The debates around these themes led to the adoption of 75 resolutions, the essentials of which were enshrined in the March 4, 2018 constitution adopted by the National Assembly on April 30, 2018, despite the objections of opposition parties and other protesters. ${ }^{57}$ During research conducted for this research brief, some of these debates

\footnotetext{
${ }^{56}$ These themes included the following: (1) the form of the state; (2) the reform of the national institutions; (3) the parliamentary system; (4) the consolidation of peace, national unity, and stability, as well as the rule of law and good governance; (5) judicial reform; and (6) the promotion of women and youth.

${ }^{57}$ The adoption of the new constitution established Chad's Fourth Republic. The reforms included fundamental changes well beyond the scope of a simple amendment. The dissolution of the Prime Minister's office represents, perhaps, the most significant change. Protesters and the opposition called for the organization of a referendum so that all Chadian citizens could vote for or against the adoption of these reforms, but the ruling party and government ignored these calls.
} 
and the subsequently adopted reforms provided evidence of the government's policies regarding the place of religion in public life.

Specifically, the reform introducing a confessional oath of office that sparked significant debate between religious communities in Chad. Article 55 of the new constitution stipulates: "certain categories of public officials and state agents must declare their assets when entering and leaving their posts and take an oath according to the confessional formula enshrined in the law." The addition of an oath based on an official's religious beliefs raised many concerns within religious communities, especially the different Christians communities. Christians expressed very clear reservations as to the desirability of such an oath, which they argued violates their doctrinal principles.

A dramatic showdown between the Supreme Court - the institution responsible for overseeing the oaths of office of all government ministers - and two newly appointed ministers underscored the depth of discomfort felt by some in religious communities opposed to this new constitutional provision. First, Madame Amane Djibergui, selected to be Minister of Civil Aviation, refused to swear her oath, which she maintained was against her faith; instead, she proposed a written commitment. The President of the Supreme Court refused her proposal and subsequently dismissed Mrs. Djibergui. President Déby's Chief of Staff replaced Mrs. Djibergui, and the President of the Supreme Court administered the oath to her replacement immediately. Second, Madame Madeleine Alingué, Minister of the Post, New Information and Communication Technologies and Government Spokesperson, arrived before the President of the Supreme Court and began to recite her oath of office. As she repeated the oath, she replaced the phrase ". . before Allah ..." with ". . . before God." The President of the Supreme Court called her to order, demanding that she respect the phrase of the oath or simply leave the place; the minister decided to leave. Later, on the instructions of the President Déby, Madame Madeleine Alingué was recalled, and her oath with "... before God ...", although not the official formulation, was accepted by the Supreme Court.

For some, these acts do not present a serious concern. They are viewed as simple questions of terminology: "God" or "Allah." For others, there is something more nefarious than a terminological debate; they see the actions of the President of the Supreme Court and other officials as actively seeking to undermine and erode the status of laïcite within the Chadian state. Either way, the fact that this debate is taking place highlights the increased tensions and reduced social cohesion. It also suggests that an apparent policy shift away from the secular nature of the state would only exacerbate these tensions and open the door for those seeking to promote violent extremism.

\section{INCREASINGLY "RADICAL"VIEWS IN PUBLIC DEBATES}

Groups promoting radical views are increasingly investing in public debates by favoring the kinds of religious interventions introduced by the state to further divide Chadian religious communities. This developing concern requires further investigation and research. The untimely interference of the government in relations between the different Muslim communities in Chad is part of this dynamic, and it was recently illustrated during the selection of a new president of the CSAI. 
The Tijannyya and the Wahabiyya represent two distinct Muslim traditions that are common in contemporary Chad. These two factions are vying for increased influence in Islamic affairs in Chad, a competition from which the state has officially remained apart. However, subtle support by the state for certain leaders and groups enables the competition to continue inflaming internal tensions within the broader Muslim community.

Ansar al-Sunna Muslims, who are referred to as Wahabiyya Muslims by others, define themselves as "orthodox Muslims following the Quran and the true Sunna of the Prophet." 58 They support, in their speeches and daily behavior, political Islam or a form of Islam that is present and active in the public sphere. For instance, Ansar al-Sunna members proclaim to reject the "passivity," the lack of "activism," or even the "complicity" of the Sufi orders that dominate the CSAI and that are primarily part of the Tijannyya order. Ansar al-Sunna argues that these leaders are in "connivance" with anti-Islamic forces who indulge in a "soft" and "depraved" Islam. From this perspective, the "hostility" of CSAI and the state to Ansar al-Sunna represents the desire of CSAI leaders to prevent the rise of their orthodox doctrine. Ansar al-Sunna understands this "hostility" against them as in response to their independence of spirit, their religious activism, and the large number of "intellectuals they have within them"; they interpret these actions as an attempt to muzzle their "citizen" demands. 59

While the authors were unable to fully investigate the arguments promoted by Ansar al-Sunna for this research, there is little doubt that this organization and its followers are actively attempting to further erode secularism in Chad. Research to better understand the goals of Ansar al-Sunna and groups like it is crucial for future efforts to increase community resilience, cohesion, and tolerance in the multicultural state.

\footnotetext{
${ }^{58}$ Abderamane Moussa Mahamat. 2015, « Tchad : dissolution de l'Association Ansar al Sounna almouhamaddya. » https://www.facebook.com/abdrahmanemoussa.mahamat/posts/863429363692549:0.

${ }^{59}$ All words in quotations in this paragraph are taken directly from Abderamane Moussa Mahamat, « Tchad : Dissolution de l'Association Ansar al Sounna almouhamaddya. » https://www.facebook.com/abdrahmanemoussa.mahamat/ posts/863429363692549:0.
} 


\section{Conclusion}

While this research found no evidence of a direct relationship between secular and religious dynamics within higher education and violent extremism in Chad, the research did reveal important dynamics related to disparities in secular policy and practice that should be taken into account by interventions seeking to address social conflict and increase community resiliency as a means to ward off violent extremist threats. The discussion and findings suggest that the Chadian state is increasingly involved directly in managing the perceptions and expectations of religious leaders and their followers. This development is contrary to Chad's successive constitutions that have repeatedly reaffirmed the secular nature of the state. According to the current constitution, public education is secular, and higher education should remain a non-religious, or at least religiously neutral, area. The examples from the two major higher education institutions in N'Djamena, URF and ISESCO, both of which are public, illuminate the ways in which the Chadian state implements its secular project through higher education. Presently, this regulatory role remains ambiguous, diffuse, and controversial. Indeed, as discussed, Arabic-speaking departments in bilingual education institutions function as small and autonomous islands, frequented almost exclusively by Muslims.

In institutions such as URF, the oversight of the Muslim intellectuals who lead CSAI means that religious education maintains a fundamental role in the university's curricula. Furthermore, the policy of Arabic-speaking students coming from other public institutions to take up religious examinations displays evidence of CSAI's strong administrative role and its oversight of the curricula. The state, therefore, subsidizes universities as well as madrassas without being able to ascertain, much less regulate, the secular nature of the education provided. In effect, some schools remain primarily oriented to Muslim students in the name of bilingual inclusion, despite the officially secular nature of the state and the unofficial exclusion of non-Arabic speakers.

Several additional examples point to an erosion or weakening of secularism within Chadian public administration. For instance, since the 1990s, Muslim elites have blocked the adoption of the family code; the presidency nominates the leader of the CSAI; public officials select the official who oversees the organization of the Hajj; and finally, the new oath of office was at least initially performed in the name of "Allah" for all officials, irrespective of their religion. These each represent small departures from the form of secularism that has historically characterized public administration in francophone contexts and in Chad. What remains unclear is the extent to which this is a state or government driven policy rather than an unintended consequence of the adoption of bilingualism or the influence of other actors.

\section{RECOMMENDATIONS FOR POLICY AND PRACTICE}

Based on the findings from this research, the following recommendations are proposed for policymakers and practitioners seeking to strengthen social harmony and foster crosscommunity resilience to actions undertaken by violent extremists, including Boko Haram: 
- First, higher education policy should seek to separate linguistic questions from religious considerations. Instruction in Arabic should limit its religious connotations, except for explicitly religious instruction. The status of Arabic as an official language in a secular country suggests that it develop as a language of communication, work, and the sciences like any other language in higher education. The continued overlap of instruction in the Arabic with religious identity risks deepening social divisions that may inadvertently exacerbate inter-religious tensions.

- Second, the state should reengage its role as a neutral arbiter in the management of religious issues throughout the country. More specifically, the state should not intervene inappropriately in religious affairs or manipulate religious authorities in one way or another. The increased influence of the state within the CSAI and, in turn, the administration of URF risks worsening the perceptions of state preferences for religious communities within the diverse Chadian Muslim community. Efforts to either subsidize religious education equally without indirect or direct influence of the state, or to remove state subsidies of any religiously affiliated institutions of higher education should be implemented to reinstate the secular position of state authorities and government officials.

- Third, the state should take care not to promote religious symbols and to refrain from incorporating religion into public life, as outlined in the laws of the republic. Currently, the Chadian state uses the principle of secularism in its multi-dimensional efforts to manage religious leaders. Despite the separation of religious affairs and public affairs, however, the state never ceases its interference with the management of religious affairs. These actions blur the lines between the separation of religion and the state, and the lack of clarity carries over into the administration of higher education. This effect is particularly apparent in the administration of the CSAI and, most recently, with the erosion of a strong secular constitution through the adoption of a confessional oath of office. Such actions may further exacerbate tensions between religious communities and reduce the resilience of Chadian society in warding off conflict and violent extremist threats.

- Finally, policymakers, practitioners, the government, and actors within the realm of higher education should pay closer attention to the rise of religious fundamentalism. Groups promoting radical views are increasingly investing in public debates precisely in favor of the kinds of religious interventions introduced by the state itself with the intention of further dividing Chadian religious communities. It is essential that these groups engage with other religious actors from a position of equality in relation to the state's administration of higher education. Efforts to sideline the views of groups such as Ansar al-Sunna are more likely to incite grievance than they are to promote peaceful and tolerant inter-religious and intra-religious exchanges. Institutions of higher education can play a vital role in creating a space for such debates to take place - but only when the state remains secular and neutral to all religious communities. This developing concern merits further investigation and research.

Addressing these issues will require greater dialogue and cooperation on the international, state, and local levels to ensure that ongoing dynamics do not engender increased animosities among religious actors on campus and in broader society. 


\section{FUTURE RESEARCH}

This research brief fills a significant gap in understanding the politics of religion in Chad and the implications of those politics in the higher education sector. The research brief also identifies future trends to follow that may increase vulnerability to violent extremist actors and threats within Chadian society. It is important to note, again, that the research did not elicit any findings to suggest that current grievances and social divisions in the higher education sector have or will have any connection to violent extremist threats. Rather, the research suggests that these grievances and disagreements over religion in public spaces, if left unaddressed, could reduce the resiliency of Chad's social fabric, leaving it vulnerable to conflict, polarization, and the divisive actions of violent extremist groups. Further research is needed as these dynamics continue to unfold.

Moving forward, research to inform policy and practice should focus on the following:

- How do government austerity measures impact student populations, and to what extent do these impacts exacerbate grievances that may open up space for further social divisions and polarization?

- What mechanisms already exist to connect Arabic Muslim and French non-Muslim students and communities, and how can they be further supported to reduce interreligious animosities?

Achieving a firmer grasp of these dynamics will require additional investments in locally informed research and analysis. Such investments are vital to efforts to better understand evolving social dynamics in Chad, and to design and implement more effective policies and practices to improve community resilience through increased social cohesion and harmony in Chad. 


\section{Sources}

Abakar, Mahamat Hassan. 2006. Chronique d'une enquête criminelle nationale: le cas du régime de Hissein Habré, 1982-1990. Paris: L’Harmattan.

Abderamane, Moussa Mahamat. 2015. «Tchad : dissolution de 1'Association Ansar al Sounna almouhamaddya » https://www.facebook.com/abdrahmanemoussa .mahamat/posts/863429363692549:0 (accessed January 7, 2018).

Agrama, Hussein Ali. 2012. Questioning Secularism: Islam, Sovereignty, and the Rule of Law in Modern Egypt. Chicago: University of Chicago Press.

Asad, Talal. 1993. Genealogies of Religion: Discipline and Reasons of Power in Christianity and Islam. Baltimore, MD: Johns Hopkins Press.

Bernard, H. Russel. 2011. Research Methods in Anthropology: Qualitative and Quantitative Approaches. Fifth Edition. Oxford, UK: Altamira Press.

Centre Al-Mouna. 2000. «Introduction. Quelle laïcité pour un Tchad pluriel?» In Quelle laïcité pour un Tchad pluriel?, 7-8. N'Djamena: Centre Al-Mouna.

Chapelle, Jean. 1986. Peuple tchadien, ses racines et sa vie quotidienne. Paris: L'Harmattan.

Coudray, Henry. 1998. « Langue, religion, identité, pouvoir: le contentieux linguistique franco-arabe au Tchad. ") In Contentieux linguistique arabe-francais, 19-65. N’Djamena: Centre Al Mouna.

Fitzgerald, Timothy. 2007. "Encompassing Religion, Privatized Religions and the Invention of Modern Politics." In Religion and the Secular: Historical and Colonial Formations, edited by Timothy Fitzgerald. London: Routledge.

Gali Ngothé Gatta. 2000. « Histoire et cadre juridique de la laïcité. » In Centre Al-Mouna (ed.), Quelle laïcité pour un Tchad pluriel ? N’Djamena:Centre Al Mouna, 11-20.

Hassan Abakar, Mahamat. 2006. Chronique d'une enquête criminelle nationale: le cas du régime de Hissein Habré, 1982-1990. Paris: L’Harmattan.

Hicks, Celeste. 2018. The Trial of Hissène Habré: How the People of Chad Brought a Tyrant to Justice. Chicago: University of Chicago Press.

Hoinathy, Remadji. 2015. «Études des perceptions sur les facteurs de l'insécurité et de L'extrémisme violent dans les régions frontalières du sahel, « Ce que disent 698 sahéliens ». Rapport National Tchad. Research report, HD-PNUD.

Hoinathy, Remadji, and Sally Bakari. 2018. " Le djihad du Cheikh Ahmat Ismael Bichara à Kouno, Tchad La jihad du Cheik Ismael Bichara. » In Biographies de la Radicalisation, edited by Mirjam de Bruijn, 59-74. Oxford: African Books Collective. 
Ibrahim, Ibrahim Yahaya. 2018. "Islam and Political Contestation in the Sahel: Protests, Riots, and Jihadist Insurgencies in Mauritania, Niger and Mali.” Ph.D. dissertation, University of Florida, Gainesville, Florida.

INSEED. 2012. Deuxième recensement général de la population et de l'habitat (RGPH2, 2009). Résultats globaux définitifs. N'Djamena: Institut National de la Statistique, des Etudes Economiques et Démographiques.

Kendhammer, Brandon, and Adama Ousmanou. 2018. "Islam, Higher Education, and Extremism in Cameroon: Lived Experiences and Campus Dynamics." RESOLVE Network Lake Chad Basin Series Research Brief No. 1, December.

Ladiba, Gondeu. 2011. L'émergence des organisations islamiques au Tchad: Enjeux, acteurs et territoires. Paris: L'Harmattan.

Lewis, M. Paul, editor. 2009. Ethnologue: Languages of the World. Dallas: SIL International. http://www.ethnologue.com (consulté le février 21, 2012).

Magrin, G., and Marc-Antoine Pérouse de Montclos. 2018. Crise et developpement: la région du lac Tchad à l'epreuve de Boko Haram. Paris: AFD.

Ministry of Higher Education. 2017. « Annuaire statistique. Secteur privé 2014-2015. » Ministry of Higher Education, N’Djamena.

Ngothé Gatta, Gali. 2000. «Histoire et cadre juridique de la laïcité. » In Quelle laïcité pour un Tchad pluriel ?, N'Djamena : Centre Al-Mouna, 11-20.

Seid, Abazene. 2000. «Islam et laïcité. » In Quelle laïcité pour un Tchad pluriel ?, N'Djamena : Centre Al-Mouna, 35-51.

Sounaye, Abdoulaye. 2009. "Ambiguous Secularism: Islam, Laïcité and the State in Niger." Civilisations 58 (2): 41-58.

Thurston, Alexander. 2018. "Campuses and Conflict in the Lake Chad Basin: Violent Extremism and the Politics of Religion in Higher Education." RESOLVE Network Research Report No. 1, Lake Chad Basin Research Series. Washington, DC. 


\section{About the Authors}

Remadji Hoinathy is a Chadian anthropologist. A former Ph.D. Fellow at the Max Planck Institute for Social Anthropology (Halle-Germany), he defended his thesis on oil and social change in Chad at the Martin Luther University (Halle-Wittenberg) in 2012. Since 2008, Remadji is the scientific director of the Centre de Recherches en Anthropologie et Sciences Humaines (CRASH) in N'Djaména. He is also lecturer at the Department of Anthropology at the University of N'Djaména and independent consultant and adviser for various local and international nongovernmental organizations. He currently works on issues related to religion, migration, and conflict.

Daniel Eizenga holds a Ph.D. in political science from the University of Florida. He is a postdoctoral fellow with the Centre FrancoPaix de la Chaire Raoul-Dandurand at the Université du Québec à Montréal, where his research focuses on international interventions in Sahelian Africa. He has carried out extensive fieldwork in Burkina Faso, Chad, and Senegal. His research has focused on the ways in which social forces shape regime trajectories following the adoption of multiparty elections. He has also conducted research on countering violent extremism policies and strategies in Burkina Faso and Chad.

\section{Acknowledgements}

RESOLVE would like to thank the U.S. Agency for International Development (USAID) for its generous support for this research brief and RESOLVE's research initiative in the Lake Chad Basin. RESOLVE would also like to thank the U.S. Institute of Peace for its continued support for RESOLVE Network initiatives.
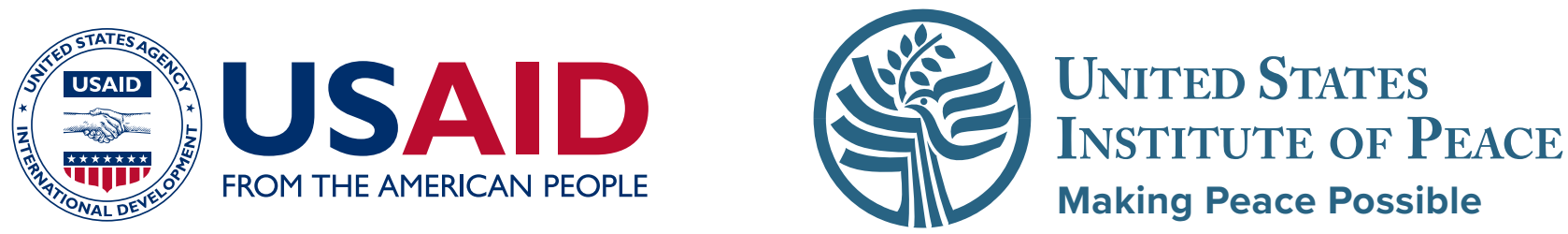

The views in this research brief are those of the authors. They do not necessarily reflect the views of the RESOLVE Network, its partners, the U.S. Institute of Peace, the U.S. Agency for International Development, or any U.S. government agency. 


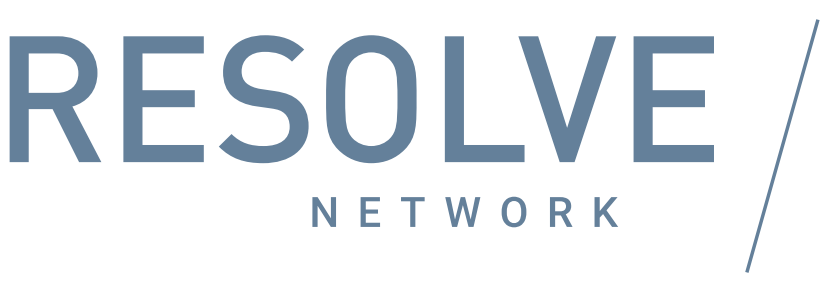

INSIGHT INTO VIOLENT EXTREMISM AROUND THE WORLD

The RESOLVE Network is a global consortium of researchers and research organizations committed to delivering fresh insight into the drivers of violent extremism around the world. The Network provides access to open-source data, tools, and curated research to ensure policy responses to violent extremism are evidence based. Members of the Network work in parts of Africa, Asia, Europe, and the Middle East to promote empirically driven, locally defined responses to conflict and to support grassroots research leadership on violent extremism.

Our partners operate in more than 25 countries where challenges with conflict are an everyday reality. We are passionate about amplifying credible local voices in the fight to mitigate the destabilizing risks of social polarization and political violence.

To learn more about the RESOLVE Network, our partners and how to get involved visit our website, www.resolvenet.org, and follow us on Twitter: @resolvenet.

\section{f $y$ in}

RESOLVE is housed at the U.S. Institute of Peace, building upon the Institute's decades-long legacy of deep engagement in conflict-affected communities. 